\title{
Heat-tolerant rice cultivars retain grain appearance quality under free-air $\mathrm{CO}_{2}$ enrichment
}

\author{
Yasuhiro Usui ${ }^{1}$, Hidemitsu Sakai ${ }^{1}$, Takeshi Tokida ${ }^{1}$, Hirofumi Nakamura ${ }^{2}$, Hiroshi Nakagawa ${ }^{3}$ \\ and Toshihiro Hasegawa ${ }^{1 *}$
}

\begin{abstract}
Background: Heat-tolerant rice cultivars have been developed as a countermeasure to poor grain appearance quality under high temperatures. Recent studies showed that elevated $\mathrm{CO}_{2}$ concentrations $\left(\mathrm{E}-\left[\mathrm{CO}_{2}\right]\right)$ also reduce grain quality. To determine whether heat-tolerant cultivars also tolerate $\mathrm{E}-\left[\mathrm{CO}_{2}\right]$, we conducted a free-air $\mathrm{CO}_{2}$ enrichment (FACE) experiment with 12 rice cultivars differing in heat tolerance.

Results: The percentage of undamaged grains of five standard cultivars (Akitakomachi, Kinuhikari, Koshihikari, Matsuribare, Nipponbare) averaged $61.7 \%$ in the ambient $\left[\mathrm{CO}_{2}\right]$ (AMB) plot and $51.7 \%$ in the FACE plot, whereas that of heat-tolerant cultivars (Eminokizuna, Wa2398, Kanto 257, Toyama 80, Mineharuka, Kanto 259, Saikai 290) averaged 73.5\% in $\mathrm{AMB}$ and $71.3 \%$ in FACE. This resulted in a significant $\left[\mathrm{CO}_{2}\right]$ by cultivar interaction. The percentage of white-base or white-back grains increased from $8.4 \%$ in AMB to $17.1 \%$ in FACE in the sensitive cultivars, but from only $2.1 \%$ in AMB to only $4.4 \%$ in FACE in the heat-tolerant cultivars.

Conclusion: Heat-tolerant cultivars retained their grain appearance quality at $\mathrm{E}-\left[\mathrm{CO}_{2}\right]$ under present air temperatures. Further improvements in appearance quality under present conditions will be needed to achieve improvements under $\mathrm{E}-\left[\mathrm{CO}_{2}\right]$, because $\mathrm{E}-\left[\mathrm{CO}_{2}\right]$ will likely lower the threshold temperature for heat stress.
\end{abstract}

Keywords: Chalky grains; Climate change; FACE (free-air $\mathrm{CO}_{2}$ enrichment); Heat-tolerant cultivars; Oryza sativa

\section{Background}

High temperatures during grain filling often cause serious damage to the grain quality of rice (Oryza sativa L.) (Terashima et al. 2001; Lanning et al. 2011; Kondo et al. 2012), reducing the proportion of first-grade rice (Hasegawa et al. 2009) or milling quality (Lyman et al. 2013). One of the main reasons for the reduction is the decreased percentage of undamaged grains, which is due to increased proportions of chalky and unfilled grains. The occurrence of chalky grains under high temperatures is attributable mainly to the inhibition of starch accumulation (Morita 2008; Morita and Nakano 2011).

Daily mean temperatures $>26^{\circ} \mathrm{C}$ during the grain-filling period cause chalkiness in the grains of japonica cultivars (Morita 2008). The cumulative temperature above $26^{\circ} \mathrm{C}$ within 15 days after heading can be used as an index of the extent of chalky grains (Lur et al. 2009). Daily mean

\footnotetext{
* Correspondence: thase@affrc.go.jp

${ }^{1}$ National Institute for Agro-Environmental Sciences, 3-1-3 Kannondai, Tsukuba, Ibaraki 305-8604, Japan

Full list of author information is available at the end of the article
}

air temperatures of $>26^{\circ} \mathrm{C}$ during grain filling are becoming more frequent in Japan. Ishigooka et al. (2011) analyzed temperature records during the 20 days after heading in the Kanto, Hokuriku, Tokai, and Kinki regions from 1978 to 2010. Large areas in Tokai and Kinki experienced an increasing frequency of high temperatures, with low interannual variability. Kanto and Hokuriku experienced high interannual variability, with $\geq 80 \%$ of paddy fields under heat stress (1994, 2007, 2010 in Kanto; 1985, 1994, 2010 in Hokuriku).

Because grain quality under heat stress varies substantially among cultivars (Nishimura et al. 2000; Wakamatsu et al. 2007), improvement of heat tolerance is one of the most effective countermeasures (Morita 2008). In fact, breeders have already developed some heat-tolerant cultivars in Japan, including 'Nikomaru' (Sakai et al. 2007; 2010), 'Kumasannochikara' (Fujii et al. 2009), 'Genkitsukushi' (Wada et al. 2010), and 'Akisakari' (Tanoi et al. 2010), and there are a number of ongoing efforts to develop cultivars with improved heat tolerance. 
The atmospheric $\mathrm{CO}_{2}$ concentration $\left(\left[\mathrm{CO}_{2}\right]\right)$ is increasing. $\left[\mathrm{CO}_{2}\right]$ has increased from $280 \mu \mathrm{mol} \mathrm{mol}^{-1}$ in 1800 to $396 \mu \mathrm{mol} \mathrm{mol}^{-1}$ in March 2013 (NOAA 2013). Its continued increase is expected to have a big influence on crop production. Elevated $\left[\mathrm{CO}_{2}\right]\left(\mathrm{E}-\left[\mathrm{CO}_{2}\right]\right)$ is expected to increase the grain yield of rice (Kobayashi et al. 2006; Hasegawa et al. 2007, Ainsworth 2008), but it decreases the protein content (Lieffering et al. 2004; Terao et al. 2005; Yang et al. 2007; Taub et al. 2008; Seneweera 2011) and the proportion of undamaged grains (Yang et al. 2007). These studies suggest that production of high-quality rice grains will become even more difficult under the expected higher air temperatures and $\left[\mathrm{CO}_{2}\right]$, but attempts to cope with both factors have yet to begin.

The mechanism of the reduction in undamaged grains under $\mathrm{E}-\left[\mathrm{CO}_{2}\right]$ is not understood, but a possible mechanism is a higher canopy temperature in $\mathrm{E}-\left[\mathrm{CO}_{2}\right]$ than in ambient $\left[\mathrm{CO}_{2}\right](\mathrm{AMB})$ conditions, which was observed in a free-air $\mathrm{CO}_{2}$ enrichment (FACE) study (Yoshimoto et al. 2005). If higher canopy temperature due to $\mathrm{E}-\left[\mathrm{CO}_{2}\right]$ is the main reason for the reduced grain appearance quality, heat-tolerant cultivars might also be resistant to the occurrence of chalky grains under $\mathrm{E}-\left[\mathrm{CO}_{2}\right]$, but this hypothesis has never been tested. Therefore, we conducted a FACE experiment using several rice cultivars to determine whether heat-tolerant cultivars could maintain high grain quality under $\mathrm{E}-\left[\mathrm{CO}_{2}\right]$.

\section{Results}

\section{Temperatures conditions and heading dates}

The daily mean air temperature throughout the growing season in 2012 was $23.7^{\circ} \mathrm{C}$, slightly higher than the 30-year average of $23.2^{\circ} \mathrm{C}$ obtained at the nearest weather station (AMeDAS at Tsukuba; $36^{\circ} 3.4^{\prime} \mathrm{N}, 140^{\circ} 7.5^{\prime} \mathrm{E}, 25 \mathrm{~m}$ above sea level). Heading date ranged from 24 July to 7 August, depending on cultivar (Table 1), but the daily mean air temperature averaged over the 20 days after heading $\left(\mathrm{T}_{\text {20DAH }}\right)$, an important determinant of grain quality, varied only in a limited range from 26.5 to $26.9^{\circ} \mathrm{C}$, which exceeded the threshold for the occurrence of chalky grains (Morita 2008). Heading date was significantly earlier in the FACE plot than in the AMB plot $(P<0.05)$, but by only 1 day, and did not affect $\mathrm{T}_{20 \mathrm{DAH}}$ (Table 1 ).

\section{Grain appearance quality}

The percentage of undamaged grains (UDG) was lower in FACE than in AMB by 5.4 percentage points (Table 2, $P=$ 0.083 ), averaged over all cultivars, but with highly significant cultivar differences $(P<0.001)$. The reduction in UDG by $\mathrm{E}-\left[\mathrm{CO}_{2}\right]$ also differed significantly among cultivars, as evidenced by a highly significant $\left[\mathrm{CO}_{2}\right] \times$ cultivar interaction $(P<0.001$; Table 2$)$. This interaction was largely associated with the interaction with cultivar group
$(P<0.001)$, whereas $\left[\mathrm{CO}_{2}\right] \times \mathrm{HT}$ cultivars was not significant. Namely, the five standard (ST) cultivars (Akitakomachi, Koshihikari, Kinuhikari, Matsuribare, and Nipponbare) showed a large reduction of 10.0 percentage points (from $61.7 \%$ to $51.7 \%$ ), whereas the heat-tolerant (HT) cultivars (Eminokizuna, Wa2398, Kanto 257, Toyama 80, Mineharuka, Kanto 259, Saikai 290) showed a reduction of only $2.2 \%$ (from $73.5 \%$ to $71.3 \%$ ). The reduction in UDG was also different among the ST cultivars, as indicated by a significant $\left[\mathrm{CO}_{2}\right] \times \mathrm{ST}$ cultivars interaction $(P<$ 0.01 , Table 2).

The reduction in UDG was due mainly to an increase in the percentage of chalky grains (Figure 1), in particular, of white-back and white-base grains (WBBG: with a chalky area in the back of the grain or close to the basal part). WBBG increased from $8.4 \%$ in $\mathrm{AMB}$ to $17.1 \%$ in FACE in the ST group, but from only $2.1 \%$ to only $4.4 \%$ in the HT group (Table 2). This resulted in a highly significant $\left[\mathrm{CO}_{2}\right] \times$ cultivar group interaction $(P<0.001)$ and a non-significant $\left[\mathrm{CO}_{2}\right] \times \mathrm{HT}$ cultivars interaction (Table 2).

Other types of chalky grains were also increased by E$\left[\mathrm{CO}_{2}\right]$ : the percentage of milky-white grains was $3.6 \%$ in AMB and $5.3 \%$ in FACE $(P<0.05$, Table 2$)$, and that of white-belly grains was $2.2 \%$ in AMB and $3.2 \%$ in FACE $(P<0.05)$, with highly significant cultivar differences $(P<0.001)$. The $\left[\mathrm{CO}_{2}\right] \times$ cultivar group interaction was significant for white-belly grains $(P<0.05)$, whereas the $\mathrm{CO}_{2} \times \mathrm{HT}$ cultivar interaction was not significant, but the magnitudes of the $\mathrm{E}-\left[\mathrm{CO}_{2}\right]$ effect and the interaction with cultivars were much smaller than in WBBG.

\section{Grain shape and weight}

Averaged over all cultivars, E- $\left[\mathrm{CO}_{2}\right]$ increased grain volume by $0.2 \mathrm{~mm}^{3}$ or $1.4 \%(P<0.05$, Table 3$)$. Among the three components of grain volume, the effect of $\mathrm{E}-\left[\mathrm{CO}_{2}\right]$ was significant only for thickness $(P<0.001$, Table 3$)$, which accounted for most of the increase in volume due to $\mathrm{E}-\left[\mathrm{CO}_{2}\right]$. The main effect of $\mathrm{E}-\left[\mathrm{CO}_{2}\right]$ on grain length was not significant, but there was a significant $\left[\mathrm{CO}_{2}\right] \times$ cultivar interaction $(P<0.01)$. There were also significant $\left[\mathrm{CO}_{2}\right] \times$ cultivar interactions for volume $(P<0.01)$ and thickness $(P<0.001)$, indicating that $\mathrm{E}-\left[\mathrm{CO}_{2}\right]$ had different effects on these traits, depending on cultivar. However, these traits are similar between the ST and HT groups among and across the $\mathrm{CO}_{2}$ treatments as evidenced by non-significant $\left[\mathrm{CO}_{2}\right] \times$ cultivar group interaction (Table 3) for any of the grain shape components.

Grain weight was also increased by E- $\left[\mathrm{CO}_{2}\right](P=0.060$, Table 3$)$, with highly significant cultivar differences $(P<$ $0.001)$ and a highly significant $\left[\mathrm{CO}_{2}\right] \times$ cultivar interaction $(P<0.001)$. In each cultivar group, there was also considerable variation in the response of grain weight to the $\mathrm{CO}_{2}$ treatment $\left(P<0.01\right.$ for the $\left[\mathrm{CO}_{2}\right] \times \mathrm{ST}$ interaction and $P<$ 
Table 1 Maturation, heading date, average temperature of $\mathrm{T}_{20 \mathrm{DAH}}$, tolerance rank, and notes for rice cultivars under test

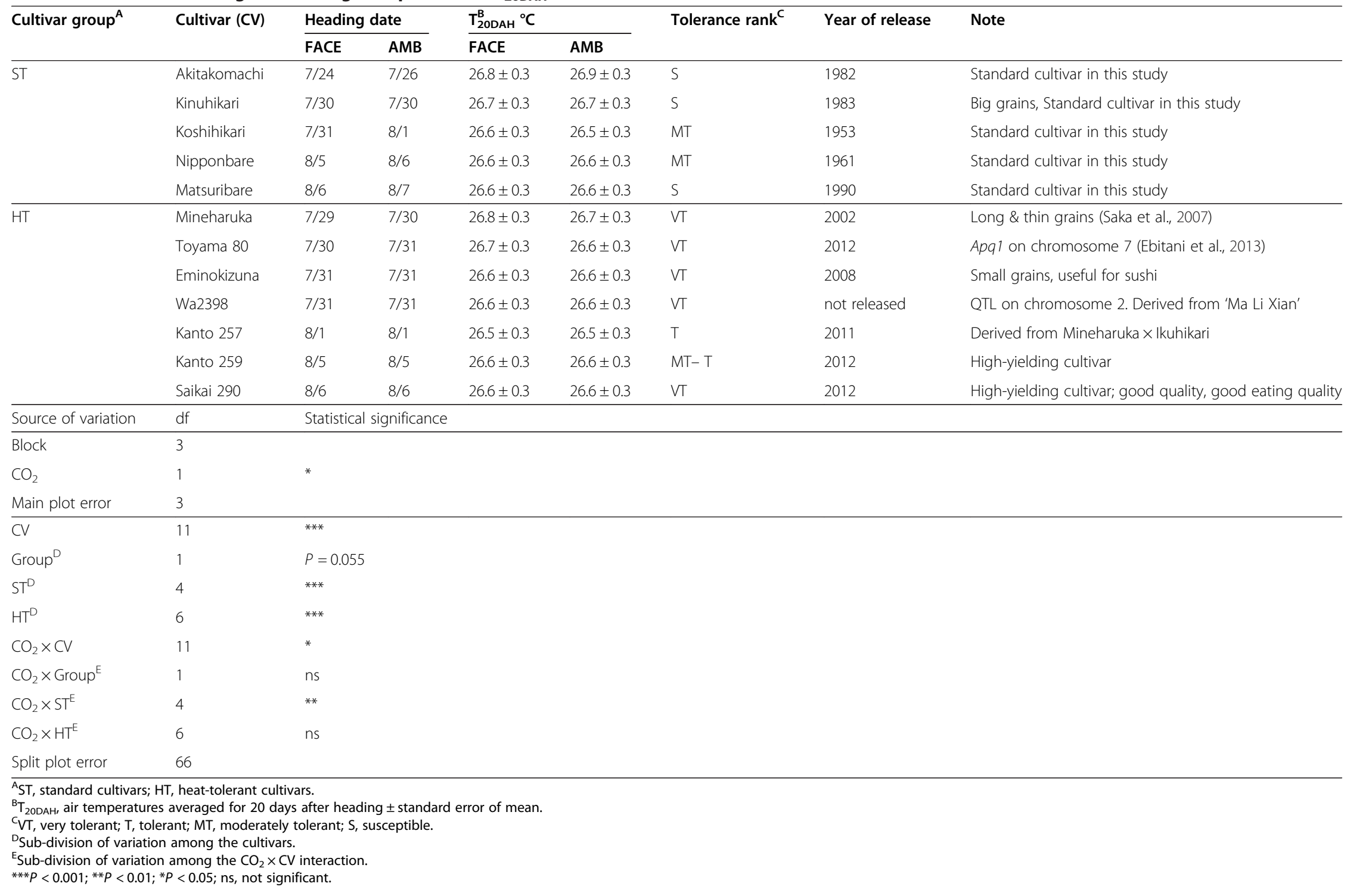


Table 2 The effect of $\mathrm{E}-\left[\mathrm{CO}_{2}\right]$ on the percentage of grains categorized by appearance

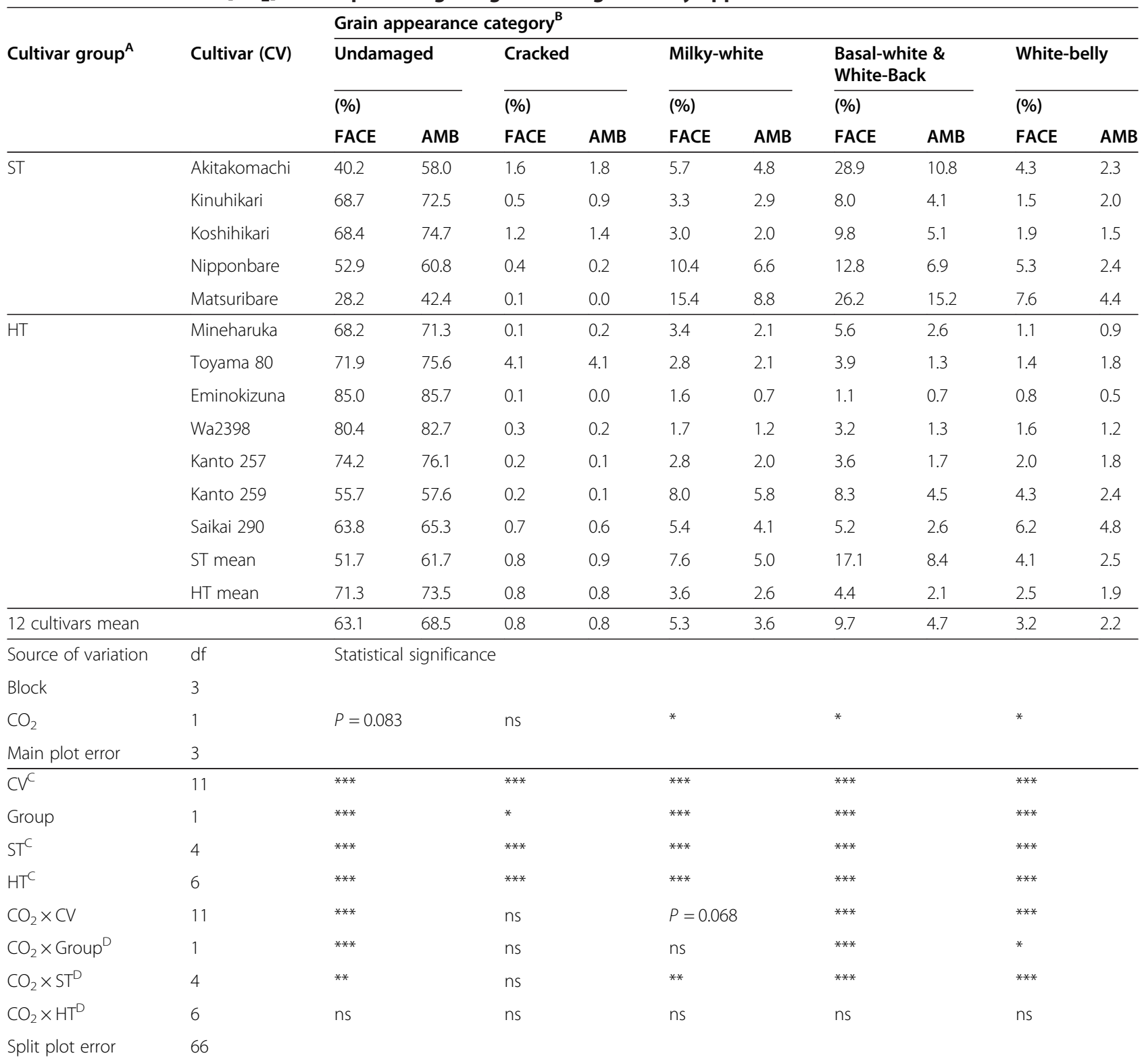

AST, standard cultivars; HT, heat-tolerant cultivars.

${ }^{B}$ Percentage of grain number by appearance categorized by grain quality inspector.

CSub-division of variation among the cultivars.

${ }^{D}$ Sub-division of variation among the $\mathrm{CO}_{2} \times \mathrm{CV}$ interaction.

${ }^{* * *} P<0.001$; ${ }^{* *} P<0.01$; ${ }^{*} P<0.05 ;$ ns, not significant; values indicate $0.05<P<0.1$.

0.001 for the $\left[\mathrm{CO}_{2}\right] \times \mathrm{HT}$ interaction, Table 3$)$, but the response was similar across cultivar groups.

\section{Grain protein content}

The grain protein content (expressed on a 15\% moisture content basis) averaged over the 12 cultivars dropped, from $62.5 \mathrm{mg} \mathrm{g}^{-1}$ in AMB to $60.2 \mathrm{mg} \mathrm{g}^{-1}$ in FACE $(P=$ 0.083 , Table 3$)$. The effect of E- $\left[\mathrm{CO}_{2}\right]$ differed significantly among cultivars, as evidenced by a $\left[\mathrm{CO}_{2}\right] \times$ cultivar interaction $(P<0.01)$, but the reduction in protein content by E- $\left[\mathrm{CO}_{2}\right]$ was similar between ST and HT cultivars: from
$62.8 \mathrm{mg} \mathrm{g}^{-1}$ in AMB to $60.7 \mathrm{mg} \mathrm{g}^{-1}$ in FACE in the ST cultivars, and from $62.3 \mathrm{mg} \mathrm{g}^{-1}$ in AMB to $59.8 \mathrm{mg} \mathrm{g}^{-1}$ in FACE in the HT cultivars (ns for the $\left[\mathrm{CO}_{2}\right] \times$ cultivar group interaction, Table 2).

Yield

The average brown rice yield of all 12 cultivars increased from $494 \mathrm{~g} \mathrm{~m}^{-2}$ in AMB to $556 \mathrm{~g} \mathrm{~m}^{-2}$ in FACE $(12.5 \%, P=$ $0.066)$. The yield enhancement in the two cultivar groups was similar-14.2\% in ST and $11.3 \%$ in HT-and there was no $\left[\mathrm{CO}_{2}\right] \times$ cultivar interaction. 


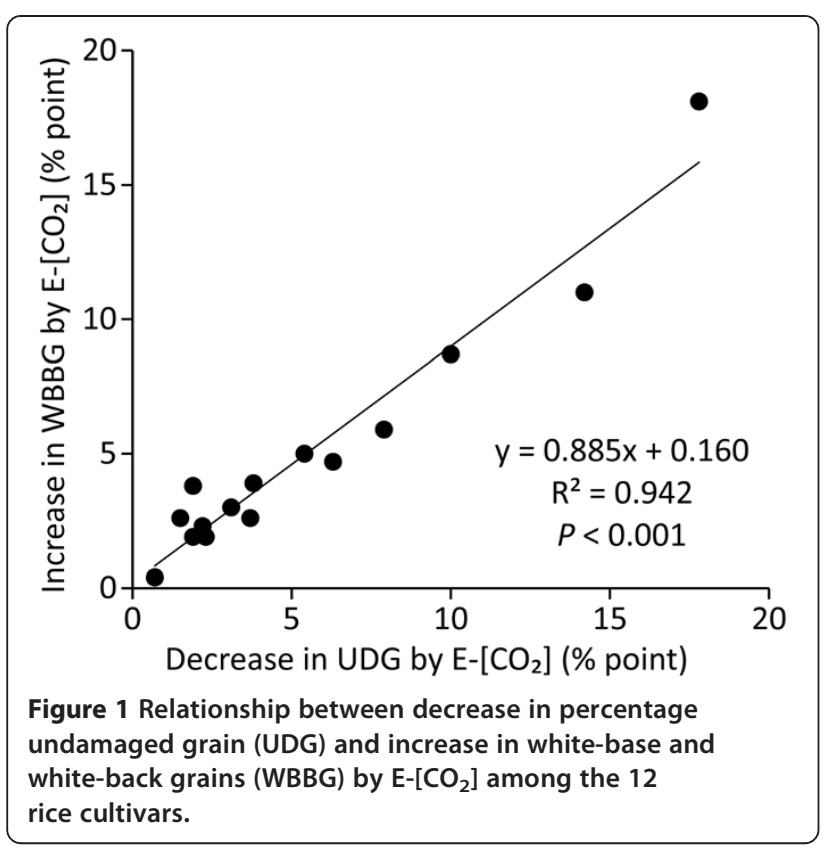

Relationships among chalky grain percentage, protein content, and grain shape

Multiple-regression analysis showed that grain shape (length, width, and thickness), weight, and protein content were not associated with cultivar differences in the UDG response to $\mathrm{E}-\left[\mathrm{CO}_{2}\right]$ (data not shown).

\section{Discussion}

$\mathrm{E}-\left[\mathrm{CO}_{2}\right]$ significantly reduced grain appearance quality by increasing the percentage of chalky grains, as was reported in a previous FACE experiment in China (Yang et al. 2007). Here, we showed that the effect of E- $\left[\mathrm{CO}_{2}\right]$ on grain appearance differed widely among cultivars, and that newly developed heat-tolerant cultivars retained high quality under $\mathrm{E}-\left[\mathrm{CO}_{2}\right]$. These results suggest that the current efforts in breeding for heat tolerance will also be effective under projected climate change.

The mechanism by which the grain appearance quality is reduced by $\mathrm{E}-\left[\mathrm{CO}_{2}\right]$ is not yet understood. $\mathrm{E}-\left[\mathrm{CO}_{2}\right]$ might be expected to improve appearance quality because of higher rates of photosynthesis and of assimilate supply to the grains. In fact, a growth chamber study revealed a modest but positive effect of $\mathrm{E}-\left[\mathrm{CO}_{2}\right]$ (Ward 2007). However, this advantage did not appear under the FACE conditions, likely because of various indirect effects of $\mathrm{E}-\left[\mathrm{CO}_{2}\right]$ on the physiology of the crop grown in open field conditions.

Among various types of chalky grains that degrade grain appearance quality, we observed significant increases in the percentage of WBBG at E- $\left[\mathrm{CO}_{2}\right]$ (Table 2), which is known to increase under high temperatures and limited $\mathrm{N}$ (Kondo et al. 2006; Wakamatsu et al. 2007). We applied the same amount of $\mathrm{N}$ fertilizers to all cultivars under both $\left[\mathrm{CO}_{2}\right]$ conditions, but E- $\left[\mathrm{CO}_{2}\right]$ decreased grain protein content (Table 3), as observed in many other studies (Lieffering et al. 2004; Terao et al. 2005; Yang et al. 2007; Taub et al. 2008; Seneweera 2011; Zhang et al. 2013). The reason for the different responses in the occurrences of chalky grain to E- $\left[\mathrm{CO}_{2}\right]$ among cultivars is not clear. If $\mathrm{N}$ related processes are involved in the occurrence of $\mathrm{E}-\left[\mathrm{CO}_{2}\right]$ induced chalkiness, one can hypothesize that cultivars with a smaller loss in grain protein content under E- $\left[\mathrm{CO}_{2}\right]$ may show a smaller reduction in grain quality. However, we did not observe noticeable differences in the grain protein response to E- $\left[\mathrm{CO}_{2}\right]$ between ST and HT groups. Some HT cultivars with a small reduction of grain quality also showed a slightly larger reduction of protein content than ST cultivars. This suggests that the quantity of protein does not have direct relevance to the response of appearance quality to $\mathrm{E}-\left[\mathrm{CO}_{2}\right]$. While we need further studies to determine whether the quantity or activity of specific proteins or enzymes plays a role in the response, the rates of chalkiness could be reduced even with a lower protein content, which is highly important for eating quality.

$\mathrm{E}-\left[\mathrm{CO}_{2}\right]$ reduces leaf stomatal conductance, which is commonly observed across many plant species (reviewed by Ainsworth and Rogers 2007). This could result in a higher canopy temperature under $\mathrm{E}-\left[\mathrm{CO}_{2}\right]$ than under ambient $\left[\mathrm{CO}_{2}\right]$ because of reduced transpirational cooling. We did not measure canopy or panicle temperatures in this study, but a previous rice FACE study reported a 0.2 to $1^{\circ} \mathrm{C}$ increase in canopy temperature by $\mathrm{E}-\left[\mathrm{CO}_{2}\right]$ (Yoshimoto et al. 2005), which likely occurred in our FACE experiment. Some recent studies highlighted the importance of canopy temperature rather than air temperature in heat stress (Matsui et al. 2007; Julia and Dingkuhn 2013; Zhao and Fitzgerald 2013). These results suggest that E- $\left[\mathrm{CO}_{2}\right]$ induces chalky grains through increased canopy or panicle temperature. Evidence also exists that canopy temperatures vary significantly among genotypes (Takai et al. 2010), so the difference in foliage temperatures may partially account for the cultivar differences in the response to $\mathrm{E}-\left[\mathrm{CO}_{2}\right]$. The canopy microclimate of different cultivars could also be an important subject for future study.

Grain appearance quality often varies from year to year with seasonal and weather conditions. The loss of grain quality due to hot summers has been reported recently both in Japan and elsewhere (e.g., Kondo et al. 2012; Lyman et al. 2013). At the Tsukuba FACE site, we tested Koshihikari in 2010 and 2011 also, when the temperatures during the grain-filling period were higher than in 2012 . As expected, UDG in AMB in these two years was smaller than in 2012. When we combined these two additional data points with those of the ST group in the 2012 season, the difference in UDG between FACE and AMB became larger as UDG in AMB decreased (Figure 2). This suggests that the negative effect of $\mathrm{E}-\left[\mathrm{CO}_{2}\right]$ on UDG can be 
Table 3 The effect of $\mathrm{E}-\left[\mathrm{CO}_{2}\right]$ on shape, protein content, 1000-grain weight and brown rice yield

\begin{tabular}{|c|c|c|c|c|c|c|c|c|c|c|c|c|c|c|c|}
\hline \multirow{3}{*}{ Cultivar Group $^{A}$} & \multirow{3}{*}{ Cultivar (CV) } & \multirow{2}{*}{\multicolumn{2}{|c|}{$\begin{array}{l}\text { Grain volume } \\
\left(\mathrm{mm}^{3}\right)\end{array}$}} & \multicolumn{6}{|c|}{ Grain shape } & \multirow{2}{*}{\multicolumn{2}{|c|}{$\begin{array}{l}\text { 1000-grain } \\
\text { weight }^{\mathrm{B}}(\mathrm{g})\end{array}$}} & \multirow{2}{*}{\multicolumn{2}{|c|}{$\begin{array}{l}\text { Gain protein } \\
\text { content }^{\mathrm{B}}\left(\mathrm{mg} \mathrm{g}^{-1}\right)\end{array}$}} & \multirow{2}{*}{\multicolumn{2}{|c|}{$\begin{array}{l}\text { Brown rice } \\
\text { yield }^{B}\left(\mathrm{~g} \mathrm{~m}^{-2}\right)\end{array}$}} \\
\hline & & & & \multicolumn{2}{|c|}{$\begin{array}{l}\text { Length } \\
(\mathrm{mm})\end{array}$} & \multicolumn{2}{|l|}{$\begin{array}{l}\text { Width } \\
(\mathrm{mm})\end{array}$} & \multicolumn{2}{|c|}{$\begin{array}{l}\text { Thickness } \\
(\mathrm{mm})\end{array}$} & & & & & & \\
\hline & & FACE & AMB & FACE & AMB & FACE & AMB & FACE & AMB & FACE & AMB & FACE & AMB & FACE & AMB \\
\hline \multirow[t]{5}{*}{ ST } & Akitakomachi & 14.3 & 14.2 & 5.08 & 5.08 & 2.71 & 2.71 & 1.99 & 1.98 & 22.0 & 22.2 & 63.5 & 63.9 & 581 & 567 \\
\hline & Kinuhikari & 14.5 & 14.4 & 4.95 & 4.97 & 2.80 & 2.80 & 2.00 & 1.98 & 22.6 & 22.2 & 64.3 & 66.0 & 577 & 517 \\
\hline & Koshihikari & 14.1 & 14.3 & 5.01 & 5.05 & 2.77 & 2.79 & 1.94 & 1.95 & 21.6 & 21.8 & 57.4 & 63.0 & 679 & 604 \\
\hline & Nipponbare & 14.6 & 13.9 & 5.04 & 4.96 & 2.76 & 2.74 & 2.01 & 1.96 & 22.1 & 21.4 & 58.0 & 61.3 & 415 & 374 \\
\hline & Matsuribare & 13.4 & 13.0 & 4.96 & 4.92 & 2.67 & 2.68 & 1.94 & 1.89 & 20.7 & 19.4 & 60.1 & 59.9 & 580 & 419 \\
\hline \multirow[t]{9}{*}{ HT } & Mineharuka & 15.0 & 14.8 & 5.39 & 5.38 & 2.62 & 2.62 & 2.03 & 2.01 & 22.5 & 22.2 & 56.4 & 63.1 & 535 & 518 \\
\hline & Toyama 80 & 14.1 & 14.1 & 4.96 & 4.99 & 2.77 & 2.76 & 1.96 & 1.95 & 21.7 & 21.6 & 53.3 & 56.6 & 578 & 557 \\
\hline & Eminokizuna & 14.0 & 13.9 & 5.01 & 5.02 & 2.64 & 2.65 & 2.02 & 2.00 & 21.4 & 21.8 & 74.9 & 72.5 & 535 & 496 \\
\hline & Wa2398 & 14.2 & 14.1 & 5.00 & 5.02 & 2.76 & 2.77 & 1.96 & 1.94 & 21.3 & 21.6 & 65.1 & 67.4 & 540 & 457 \\
\hline & Kanto 257 & 14.8 & 14.8 & 5.34 & 5.33 & 2.69 & 2.70 & 1.97 & 1.97 & 22.7 & 23.3 & 55.0 & 59.8 & 564 & 538 \\
\hline & Kanto 259 & 14.7 & 13.9 & 5.21 & 5.12 & 2.72 & 2.72 & 1.98 & 1.91 & 22.6 & 21.3 & 54.6 & 57.8 & 506 & 410 \\
\hline & Saikai 290 & 14.8 & 14.5 & 4.96 & 4.93 & 2.87 & 2.86 & 1.99 & 1.96 & 22.5 & 21.8 & 59.5 & 58.8 & 583 & 475 \\
\hline & ST mean & 14.2 & 14.0 & 5.01 & 5.00 & 2.74 & 2.74 & 1.98 & 1.95 & 21.8 & 21.4 & 60.7 & 62.8 & 566 & 496 \\
\hline & HT mean & 14.5 & 14.3 & 5.12 & 5.11 & 2.72 & 2.72 & 1.99 & 1.96 & 22.1 & 21.9 & 59.8 & 62.3 & 549 & 493 \\
\hline 12 cultivars mean & & 14.4 & 14.2 & 5.08 & 5.06 & 2.73 & 2.73 & 1.98 & 1.96 & 22.0 & 21.7 & 60.2 & 62.5 & 556 & 494 \\
\hline Source of variation & $d f$ & \multicolumn{14}{|c|}{ Statistical significance } \\
\hline Block & 3 & & & & & & & & & & & & & & \\
\hline $\mathrm{CO}_{2}$ & 1 & \multicolumn{2}{|l|}{ * } & \multirow{2}{*}{\multicolumn{2}{|c|}{ ns }} & \multirow{2}{*}{\multicolumn{2}{|c|}{ ns }} & \multirow{2}{*}{\multicolumn{2}{|c|}{$* * *$}} & \multirow{2}{*}{\multicolumn{2}{|c|}{$P=0.060$}} & \multicolumn{2}{|l|}{$P=0.083$} & \multicolumn{2}{|c|}{$P=0.066$} \\
\hline Main plot error & 3 & & & & & & & & & & & & & & \\
\hline $\mathrm{CV}$ & 11 & $* * *$ & & $* * *$ & & $* * *$ & & $* * *$ & & $* * *$ & & $* * *$ & & $* * *$ & \\
\hline Group $^{c}$ & 1 & $* * *$ & & $* * *$ & & $* * *$ & & $* *$ & & $* * *$ & & ns & & ns & \\
\hline$S T^{C}$ & 4 & $* * *$ & & $* * *$ & & $* * *$ & & $* * *$ & & $* * *$ & & $* * *$ & & $* * *$ & \\
\hline$H T^{C}$ & 6 & $* * *$ & & $* * *$ & & $* * *$ & & $* * *$ & & $* * *$ & & $* * *$ & & $P=0.05$ & \\
\hline $\mathrm{CO}_{2} \times \mathrm{CV}$ & 11 & $* *$ & & $* *$ & & ns & & $* * *$ & & $* * *$ & & $* *$ & & ns & \\
\hline $\mathrm{CO}_{2} \times$ Group $^{\mathrm{D}}$ & 1 & ns & & ns & & ns & & ns & & ns & & ns & & ns & \\
\hline $\mathrm{CO}_{2} \times \mathrm{ST}^{\mathrm{D}}$ & 4 & $* *$ & & $* *$ & & ns & & $* *$ & & $* *$ & & $P=0.095$ & & ns & \\
\hline $\mathrm{CO}_{2} \times \mathrm{HT}^{\mathrm{D}}$ & 6 & * & & $*$ & & ns & & $* *$ & & $* * *$ & & $* *$ & & ns & \\
\hline Split plot error & 66 & & & & & & & & & & & & & & \\
\hline
\end{tabular}

exacerbated in hotter summers. In the HT group, the same relationship was not significant, suggesting that these cultivars are likely to show a smaller loss of grain quality under $\mathrm{E}-\left[\mathrm{CO}_{2}\right]$, but this needs to be tested under harsher environments.

E- $\left[\mathrm{CO}_{2}\right]$ induced WBBG-type chalkiness, which has long been known as a result of high sensitivity to heat (Nagato and Ebata 1965). All of the HT cultivars showed good appearance quality under both $\left[\mathrm{CO}_{2}\right]$ conditions, indicating that selection for heat tolerance can be effective for improving grain appearance quality under E$\left[\mathrm{CO}_{2}\right]$. The recent identification of a number of QTLs for heat-induced increases in white-back or white-base chalkiness (e.g., Kobayashi et al. 2007; 2013; Ebitani et al. 2008) will support marker-assisted selection for high appearance quality under high temperatures and possibly under E- $\left[\mathrm{CO}_{2}\right]$. However, some of these QTLs may not be effective above a certain threshold; for instance, a $\mathrm{T}_{20 \mathrm{DAH}}$ of $27^{\circ} \mathrm{C}$ (Kobayashi et al. 2007). Our results suggest that projected rises in $\left[\mathrm{CO}_{2}\right]$ will lower the threshold for heatinduced chalkiness, so continued efforts will be needed to increase the level of heat tolerance. In the meantime, we need to improve our mechanistic understanding of how heat-tolerant cultivars could be buffered against loss of 


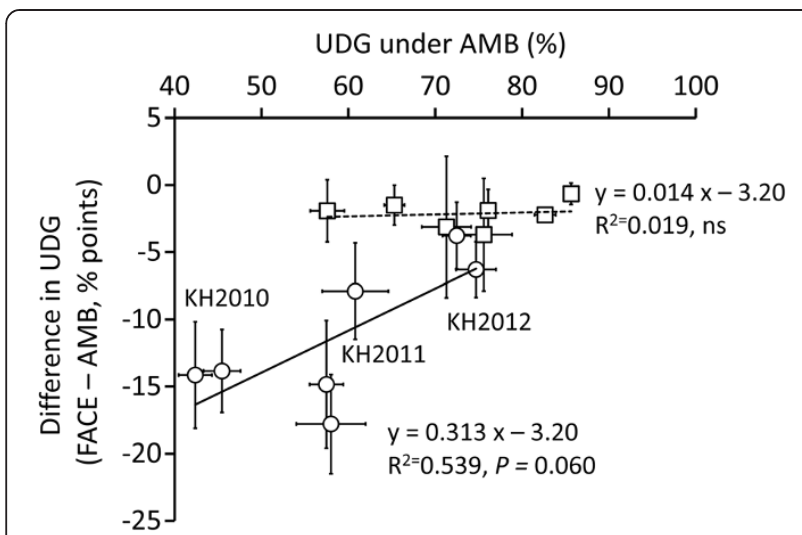

Figure 2 Relationship between the percentage of undamaged grains (UDG) in AMB and difference in UDG between FACE and AMB. $\mathrm{KH}=$ Koshihikari (tested in 2010-2012). o, Standard cultivar; $\square$, Heat-tolerant cultivar. Error bars represent standard error of the mean $(n=4)$.

grain quality under elevated $\left[\mathrm{CO}_{2}\right]$ in order to identify promising traits for future breeding programs.

Under the projected future climate change, both high productivity and high quality will be needed. In our previous study, we suggested the potential for improving productivity under E- $\left[\mathrm{CO}_{2}\right]$ by showing cultivar differences of $3 \%$ to $36 \%$ in grain yield responses to $\mathrm{E}-\left[\mathrm{CO}_{2}\right]$ (Hasegawa et al. 2013). Here, we did not observe a significant interaction in grain yield between $\left[\mathrm{CO}_{2}\right]$ and cultivars, but neither did we find a negative relationship between quality and grain yield $\left(r^{2}=0.0281, n s\right)$. This suggests that both productivity and quality traits can be improved separately or simultaneously, but continued efforts are needed.

\section{Conclusions}

These results indicate that heat-tolerant cultivars retain their grain quality under $\mathrm{E}-\left[\mathrm{CO}_{2}\right]$ better than standard cultivars. Thus, an improvement in grain quality under present conditions will achieve an improvement under $\mathrm{E}-\left[\mathrm{CO}_{2}\right]$. However, continued efforts will be needed to improve heat tolerance, because $\mathrm{E}-\left[\mathrm{CO}_{2}\right]$ will likely decrease the threshold temperature for heat stress.

\section{Methods}

\section{Study site}

We conducted the FACE experiment at the Tsukuba FACE site, which was established in farmers' fields in Tsukubamirai City, Ibaraki Prefecture, Japan $\left(35^{\circ} 58^{\prime} \mathrm{N}\right.$, $139^{\circ} 60^{\prime} \mathrm{E}, 10 \mathrm{~m}$ above sea level). The climate is humid subtropical with an average annual temperature of $13.8^{\circ} \mathrm{C}$ and annual precipitation of $1280 \mathrm{~mm}$. The soil is a Fluvisol, which is typical of alluvial areas. The soil properties at the site are described by Hasegawa et al. (2013); in brief, the soil contains $21.4 \mathrm{mg} \mathrm{g}^{-1}$ total $\mathrm{C}$ and $1.97 \mathrm{mg} \mathrm{g}^{-1}$ total $\mathrm{N}$, has a bulk density of $0.87 \mathrm{Mg} \mathrm{m}^{-3}$, and has a composition of $36 \%$ sand, $40 \%$ silt, and $23 \%$ clay.

\section{$\mathrm{CO}_{2}$ treatment}

The method for controlling $\left[\mathrm{CO}_{2}\right]$ in an open field is described by Nakamura et al. (2012). In brief, four blocks (replicates) were established in paddy fields, each consisting of two octagonal plots $\left(240 \mathrm{~m}^{2}, 17 \mathrm{~m}\right.$ across): an ambient $\left[\mathrm{CO}_{2}\right]$ (AMB) plot and an E- $\left[\mathrm{CO}_{2}\right]$ (FACE) treatment plot. The FACE plots were equipped with emission tubes around the perimeter, which released $\mathrm{CO}_{2}$ from the windward side to keep the $\left[\mathrm{CO}_{2}\right]$ measured at the central point at ca. $200 \mu \mathrm{mol} \mathrm{mol}^{-1}$ above the AMB level. The seasonlong daytime average $\left[\mathrm{CO}_{2}\right]$ in 2012 was $392 \mu \mathrm{mol} \mathrm{mol}^{-1}$ in the AMB plots and $577 \mu \mathrm{mol} \mathrm{mol}^{-1}$ in the FACE plots.

\section{Cultural practices and growth conditions}

We applied compound fertilizer to supply $4.36 \mathrm{~g} \mathrm{~m}^{-2}$ of phosphorus (P) and $8.30 \mathrm{~g} \mathrm{~m}^{-2}$ of potassium (K) on 9 April 2012, before plowing. We applied a total of $8 \mathrm{~g} \mathrm{~m}^{-2}$ of nitrogen (N) fertilizer: $2 \mathrm{~g} \mathrm{~m}^{-2}$ as urea, $4 \mathrm{~g} \mathrm{~m}^{-2}$ as one controlled-release fertilizer (type LP100), and $2 \mathrm{~g} \mathrm{~m}^{-2}$ as another controlled-release urea (type LP140, JCAM Agri. Co., Tokyo, Japan). Right after $\mathrm{N}$ application, we puddled (tilled) the field for uniformity on 17 May in 2012.

In each plot, we planted 7 heat-tolerant cultivars and 5 standard cultivars (Table 1). Seedlings were transplanted by hand on 23-25 May 2012 at a spacing of $30 \mathrm{~cm} \times$ $15 \mathrm{~cm}\left(22.2 \mathrm{hills}^{-2}\right)$. Seedlings of Akitakomachi and Koshihikari, which we sampled during the growing season for other studies, were planted in areas of $2.7 \mathrm{~m} \times 1.95 \mathrm{~m}$ (Akitakomachi) and $3 \mathrm{~m} \times 5.4 \mathrm{~m}$ (Koshihikari) at three seedlings per hill. The others were planted in areas of $1.2 \mathrm{~m} \times 0.45 \mathrm{~m}$ (12 hills) per cultivar in each plot; they were randomly allocated within the plot.

\section{Measurement}

We sampled 21 hills of Akitakomachi and Koshihikari and 12 hills of the others (11 of Wa2398 in one FACE plot) in each of the four replicates for grain yield components and quality measurement. After the materials were dried under a rain shelter, we measured the total aboveground plant weight and panicle number. After threshing, we measured the total weight of the spikelets. Each spikelet sample was then split into three subsamples. One subsample was dehulled to determine the brown rice weight; this sample was then used for grain quality measurement in this study. The other 2 subsamples were used in another study. We measured the moisture content of the grains with a grain moisture tester (Riceter $\mathrm{f}$, Kett Electric Laboratory, Tokyo, Japan). The brown rice yield and 1000-grain weight were expressed on a $15 \%$ moisture content basis. 
We measured grain appearance quality (different types of chalky grains) and grain shape (width, length, thickness) with a grain quality inspector (RGQI20A; Satake Corp., Hiroshima, Japan) equipped with image analysis software. White-back and white-base grains were counted together, and are reported as WBBG. The grain volume was calculated as for an ellipsoidal body: $4 / 3 \times \pi \times$ length $/ 2 \times$ width/ $2 \times$ thickness $/ 2$. $\mathrm{N}$ was measured with an $\mathrm{NC}$ analyzer (Sumigraph NC-22 F; Sumica Chemical Analysis Service, Tokyo, Japan). The protein content (\%) was calculated as $\mathrm{N}(\%) \times 5.95($ MEXT 2005) and corrected to $15 \%$ moisture content.

\section{Statistics}

We conducted an analysis of variance for the 12 cultivars, using a split-plot design, where $\left[\mathrm{CO}_{2}\right]$ was treated as the main factor and cultivar as the split factor, with four replications, in the SAS software, using the GLM procedure (SAS Institute Inc., Cary, NC, USA). To test differences between cultivar groups, we separated the sums of squares for the split-plot components into the following sources of variation; between-cultivar groups, within HT and ST groups and their interactions with $\left[\mathrm{CO}_{2}\right]$ (Tables $\left.1,2,3\right)$. To examine whether cultivar differences in the UDG response to $\mathrm{E}-\left[\mathrm{CO}_{2}\right]$ were associated with grain shapes (length, width, thickness), grain weight and grain protein content, we conducted multiple regression of the increase in UDG by elevated $\left[\mathrm{CO}_{2}\right]$ on the log-transformed response ratio (FACE/ ambient) of grain shape parameters. Statistical significance is indicated for $P<0.001,0.01$, or 0.05 , and actual $P$ values are presented where $0.05<P<0.1$.

\section{Abbreviations}

AMB: Ambient; FACE: Free-air $\mathrm{CO}_{2}$ enrichment; $\mathrm{HT}$ : Heat-tolerant cultivars; ST: Standard cultivars; $T_{20 D A H}$ : Air temperatures averaged for 20 days after heading; UDG: Percentage of non-damaged grains; WBBG: White-based and white-back grains.

\section{Competing interests}

The authors declare that they have no competing interests.

\section{Authors' contributions}

TH planned and supervised the project. HS and TT designed the experimental plot. $\mathrm{YU}, \mathrm{HS}, \mathrm{TT}, \mathrm{HN}$, and $\mathrm{TH}$ conducted the FACE experiment. $\mathrm{HN}$ managed the $\left[\mathrm{CO}_{2}\right]$ treatments and monitored the environmental variables. YU collected and analyzed the data. $\mathrm{HN}$ advised on grain quality measurements and interpretation of the results. $\mathrm{YU}$ and $\mathrm{TH}$ wrote the paper. All authors read and approved the final manuscript.

\footnotetext{
Acknowledgements

We thank Dr. Hiroshi Nemoto, Mr. Yoshihiro Sunohara, and Dr. Yoshinobu Takeuchi of the National Agricultural Research Organization, and Dr. Takeshi Ebitani of the Toyama Prefectural Agricultural, Forestry and Fisheries Research Center for advice on the selection of cultivars and for providing seeds. We also thank Dr. Tetsuhisa Miwa of the National Institute for Agro-Environmental Sciences for his advice on statistical methods and team member of Tsukuba FACE for their help in the field experiments. This work was supported in part by the Ministry of Agriculture, Forestry and Fisheries, Japan, through a research project entitled 'Development of technologies for mitigation and adaptation to climate change in agriculture, forestry and fisheries', and in part by a Grant-in-Aid
}

for Scientific Research on Innovative Areas (no. 24114711) by the Japan Society for the Promotion of Science, as part of the project entitled "Comprehensive studies of plant responses to high $\mathrm{CO}_{2}$ world by an innovative consortium of ecologists and molecular biologists."

\section{Author details}

${ }^{1}$ National Institute for Agro-Environmental Sciences, 3-1-3 Kannondai, Tsukuba, Ibaraki 305-8604, Japan. ${ }^{2}$ Taiyo Keiki Co. Ltd, 1-12-3, Nakajujo, Kita-ku, Tokyo 114-0032, Japan. ${ }^{3}$ NARO Agricultural Research Center, 3-1-1 Kannondai, Tsukuba, Ibaraki 305-8666, Japan.

Received: 27 January 2014 Accepted: 25 April 2014

Published online: 21 May 2014

\section{References}

Ainsworth EA (2008) Rice production in a changing climate: a meta-analysis of responses to elevated carbon dioxide and elevated ozone concentration. Global Change Biol 14:1642-1650. doi:10.1111/j.1365-2486.2008.01594.x

Ainsworth EA, Rogers A (2007) The response of photosynthesis and stomatal conductance to rising $\left[\mathrm{CO}_{2}\right]$ : mechanism and environmental interaction. Plant Cell Environ 30:258-270. doi:10.1111/j.1365-3040.2007.01641.x

Ebitani T, Yamamoto Y, Yano M, Funane M (2008) Identification of quantitative trait loci for grain appearance using chromosome segment substitution line in rice. Breeding Res 10:91-99, doi.org/10.1270/jsbbr.10.91

Ebitani T, Murata Y, Iyama Y, Yamaguchi T, Fujita T (2013) Development of the novel line, Toyama 80, with Koshihikari genetic background can produce superior grains for appearance quality under high temperature stress. Breeding Res 15:233

Fujii Y, Mitsukawa M, Sakanashi J, Ueno I, Izumi K, Hatakeyama S, Araki S, Kurata K, Tanaka M (2009) Breeding and characters of a new cultivar 'Kumasannochikara' with resistance to high-temperature during ripening period. Res Bull Kumamoto Pref Agric Res Cent 16:1-10

Hasegawa T, Kuwagata T, Nishimori M, Ishigooka Y, Murakami M, Yoshimoto M, Kondo M, Ishimaru T, Sawano S, Masaki Y, Matsuzaki H (2009) Recent warming trends and rice growth and yield in Japan. In: Hasegawa T, Sakai H (eds) Proceeding of the MARCO Symposium. National Institute for AgroEnvironmental Sciences, Tsukuba, Japan, pp 44-51, 5-9 October 2009

Hasegawa T, Shimono H, Yang LX, Kim HY, Kobayashi T, Sakai H, Yoshimoto M, Lieffering M, Ishiguro K, Wang YL, Zhu JG, Kobayashi K, Okada M (2007) Response of rice to increasing $\mathrm{CO}_{2}$ and temperature: Recent findings from large-scale free-air $\mathrm{CO}_{2}$ enrichment (FACE) experiments. In: Aggarwal P, Ladha J, Singh R, Devakumar C, Hardy B (eds) Proceedings of the 26th International Rice Conference. Los Baños (Philippines) and New Delhi (India): International Rice Research Institute, Indian Council of Agricultural Research, and National Academy of Agricultural Sciences. Macmillan India Ltd, New Delhi, India, pp 439-447, 9-12 October 2006

Hasegawa T, Sakai H, Tokida T, Nakamura H, Zhu C, Usui Y, Yoshimoto M, Fukuoka M, Wakatsuki H, Katayanagi N, Matsunami T, Kaneta Y, Sato T, Takakai F, Sameshima R, Okada M, Mae T, Makino A (2013) Rice cultivar responses to elevated $\mathrm{CO}_{2}$ at two free-air $\mathrm{CO}_{2}$ enrichment (FACE) sites in Japan. Funct Plant Biol 40:148-159, doi.org/10.1071/FP12357

Ishigooka Y, Kuwagawa T, Nishimori M, Hasegawa T, Ohno H (2011) Spatial characterization of recent hot summers in Japan with agro-climatic indices related to rice production. J Agric Meteorol 67:209-224, doi.org/10.2480/agrmet.67.4.5

Julia C, Dingkuhn M (2013) Predicting temperature induced sterility of rice spikelets requires simulation of crop-generated microclimate. Europ J Agronomy 49:50-60, doi.org/10.1016/j.eja.2013.03.006

Kobayashi A, Bao G, Ye S, Tomita K (2007) Detection of Quantitative Trait Loci for white-back and basal-white kernels under high temperature stress in japonica rice varieties. Breed Sci 57:107-116. doi:10.1270/jsbbs.63.339

Kobayashi A, Sonoda J, Sugimoto K, Kondo M, Iwasawa N, Hayashi T, Tomita K, Yano M, Shimizu T (2013) Detection and verification of QTLs associated with heatinduced quality decline of rice (Oryza sativa L.) using recombinant inbred lines and near-isogenic lines. Breed Sci 63:339-346, doi.org/10.1270/jsbbs.63.339

Kobayashi K, Okada M, Kim HY, Lieffering M, Miura S, Hasegawa T (2006) Paddy rice responses to free-air $\left[\mathrm{CO}_{2}\right]$ enrichment. In: Nösberger J, Long SP, Norby RJ, Stitt M, Hendrey GR, Blum H. Managed ecosystems and $\mathrm{CO}_{2}$ : Case studies, processes, and perspectives. Springer-Verlag, Berlin, pp 87-104

Kondo M, Iwasawa N, Yoshida H, Nakagawa H, Ohno H, Nakazono K, Usui Y, Tokida T, Hasegawa T, Kuwagata T, Morita S, Nagta K (2012) Factors influencing the appearance quality in rice under high temperature in 2010. Jpn J Crop Sci 81 (Extra issue 1):120-121 
Kondo M, Morita S, Nagata K, Koyama Y, Ueno N, Hosoi J, Ishida Y, Yamakawa T, Nakayama Y, Yoshida Y, Ohashi Y, Iwai M, Odaira Y, Nakatsu S, Katsuba Z, Hajima M, Mori Y, Kimura H, Sakata M (2006) Effects of Air temperature during ripening and grain protein contents on grain chalkiness in rice. Jpn J Crop Sci 75(extra issue 2):14-15

Lanning SB, Siebenmorgen TJ, Counce PA, Ambardekar AA, Mauromoustakos (2011) Extreme nighttime air temperatures 2010 impact rice chalkiness and milling. Field Crops Res 124:132-136, doi.org/10.1016/j.fcr.2011.06.012

Lieffering M, Kim HY, Kobayashi K, Okada M (2004) The impact of elevated $\mathrm{CO}_{2}$ on the elemental concentrations of field-grown rice grains. Field Crops Res 88:279-286, doi.org/10.1016/j.fcr.2004.01.004

Lur HS, Wu YC, Chang SJ, Lao CL, Hsu CL, Kondo M (2009) Effects of high temperature on yield and grain quality of rice in Taiwan. In: Hasegawa T, Sakai H (eds) Proceeding of the MARCO Symposium. National Institute for Agro-Environmental Sciences, Tsukuba, Japan, pp 38-43, 5-9 October 2009

Lyman NB, Jagadish KSV, Nalley LL, Dixon BL, Siebenmorgen T (2013) Neglecting rice milling yield and quality underestimates economic losses from hightemperature stress. PLoS One 8:e72157. doi:10.1371/journal.pone.0072157

Matsui T, Kobayasi K, Yoshimoto M, Hasegawa T (2007) Stability of rice pollination in the field under hot and dry conditions in the Riverina region of New South Wales, Australia. Plant Prod Sci 10:57-63, doi.org/10.1626/pps.10.57

MEXT (2005) Standard tables of food composition in Japan. (Fifth revised and enlarged edition- 2005 -, http://www.mext.go.jp/b_menu/shingi/gijyutu/ gijyutu3/toushin/05031802.htm. Accessed 27 Jan 2014

Morita S (2008) Prospect for developing measures to prevent high-temperature damage to rice grain ripening. Jpn J Crop Sci 77:1-12

Morita S, Nakano H (2011) Nonstructural carbohydrate content in the stem at full heading contributes to high performance of ripening in heat-tolerant rice cultivar Nikomaru. Crop Sci 51:818-828. doi:10.2135/cropsci2010.06.0373

Nagato K, Ebata M (1965) Effects of high temperature during ripening period on the development and the quality of rice kernels. Jpn J Crop Sci 34:59-66

Nakamura H, Tokida T, Yoshimoto M, Sakai H, Fukuoka M, Hasegawa T (2012) Performance of the enlarged rice-FACE system using pure $\mathrm{CO}_{2}$ installed in Tsukuba, Japan. J Agric Meteorol 68:15-23, doi.org/10.2480/agrmet.68.1.2

Nishimura M, Kaji R, Ogawa T (2000) Varietal difference in the occurrence of coarse grain due to the high temperature stress given during the ripening period of rice plant. Breeding Res 2:17-22

NOAA (2013) http://www.esrl.noaa.gov/gmd/ccgg/trends/. Accessed 27 Jan 2014

Saka N, Terashima T, Kudo S, Kato T, Sugiura K, Endou I, Shirota M, Inoue M, Otake T (2007) A new high field resistant variety "Mineharuka" for rice blast. Res Bull Aichi Agric Res Ctr 39:95-109

Sakai M, Okamoto M, Tamura K, Kaji R, Mizobuchi R, Hirabayashi H, Fukaura S, Nishimura M, Yagi T (2007) 'Nikomaru', a new rice variety with excellent palatability and grain appearance developed for warm region of Japan. Breeding Res 9:67-73

Sakai M, Okamoto M, Tamura K, Kaji R, Mizobuchi R, Hirabayashi H, Yagi T, Nishimura M, Fukaura S (2010) 'Nikomaru', A high-yielding rice variety with superior eating quality and grain appearance under high temperature during ripening. Bull NARO Kyushu Okinawa Agric Res Cent 54:43-61

Seneweera S (2011) Effects of elevated $\mathrm{CO}_{2}$ on plant growth and nutrient partitioning of rice (Oryza sativa L.) at rapid tillering and physiological maturity. J Plant Interact 6:35-42. doi:10.1080/17429145.2010.513483

Takai T, Yano M, Yamamoto T (2010) Canopy temperature on clear and cloudy days can be used to estimate varietal differences in stomatal conductance in rice. Field Crops Res 115:165-170

Tanoi M, Tomita K, Kobayashi A, Hayashi T (2010) Heat tolerance and grain quality of a new rice cultivar 'Akisakari'. Hokuriku Crop Sci 45:3-6

Taub DR, Miller B, Allen $\mathrm{H}$ (2008) Effects of elevated $\mathrm{CO}_{2}$ on the protein concentration of food crops: a meta-analysis. Global Change Biol 14:565-575. doi:10.1111/j.1365-2486.2007.01511.x

Terao T, Miura S, Yanagihara T, Hirose T, Nagata K, Tabuchi H, Kim H-Y, Lieffering M, Okada M, Kobayashi K (2005) Influence of free-air $\mathrm{CO}_{2}$ enrichment (FACE) on the eating quality of rice. J Sci Food Agric 85:1861-1868. doi:10.1002/jsfa.2165

Terashima K, Saito Y, Sakai N, Watanabe T, Ogata T, Akita S (2001) Effects of high air temperature in summer of 1999 on ripening and grain quality of rice. Jpn J Crop Sci 70:449-458

Wada T, Tsubone M, Inoue T, Ogata T, Hamachi Y, Matsue Y, Oosato FK, Yasunaga T, Kawamura Y, Ishizuka A (2010) 'Genkitsukushi', a new cultivar with tolerance to high temperature during maturing period and high eating quality. Bull Fukuoka Agric Res Centr 29:1-9
Wakamatsu K, Sasaki O, Uezono I, Tanaka A (2007) Effects of high air temperature during the ripening period on the grain quality of rice in warm region of Japan. Jpn J Crop Sci 76:71-78

Ward RM (2007) Potential impact of temperature and carbon dioxide levels on rice quality. The University of Sydney, Dissertation

Yang LX, Wang YL, Dong GC, Gu H, Huang JY, Zhu JG, Yang HJ, Liu G, Han Y (2007) The impact of free-air $\mathrm{CO}_{2}$ enrichment (FACE) and nitrogen supply on grain quality of rice. Field Crops Res 102:128-140, doi.org/10.1016/j. fcr.2007.03.006

Yoshimoto M, Oue H, Takahashi N, Kobayashi K (2005) The effects of FACE (free-air $\mathrm{CO}_{2}$ enrichment) on temperatures and transpiration of rice panicles at flowering stage. J Agric Meteorol 60:597-600

Zhang G, Sakai H, Tokida T, Usui Y, Zhu C, Nakamura H, Yoshimoto M, Fukuoka M, Kobayashi K, Hasegawa T (2013) The effects of free-air $\mathrm{CO}_{2}$ enrichment (FACE) on carbon and nitrogen accumulation in grains of rice (Oryza sativa L.). J Exp Bot 64:3179-3188. doi:10.1093/jxb/ert154

Zhao X, Fitzgerald M (2013) Climate change: implication for the yield of edible rice. PLoS One 8:e66218. doi:10.1371/journal.pone.0066218

doi:10.1186/s12284-014-0006-5

Cite this article as: Usui et al:: Heat-tolerant rice cultivars retain grain

appearance quality under free-air $\mathrm{CO}_{2}$ enrichment. Rice 2014 7:6.

\section{Submit your manuscript to a SpringerOpen ${ }^{\circ}$ journal and benefit from:}

- Convenient online submission

- Rigorous peer review

- Immediate publication on acceptance

- Open access: articles freely available online

- High visibility within the field

- Retaining the copyright to your article

Submit your next manuscript at $>$ springeropen.com 